\title{
Menarche and First Emotional Reactions of Turkish Adolescent
}

\author{
Ayşe KARAKOÇ ${ }^{1}$ Fadime BINGÖL $L^{1}$, Ayşe Ferda OCAKÇI $I^{2}$ \\ ${ }^{1}$ Marmara University Faculty of Health Science, Istanbul, Turkey \\ ${ }^{2}$ Koc University School of Nursing, Istanbul, Turkey \\ akarakoc@marmara.edu.tr
}

\begin{abstract}
Menarche is a physiologic situation that is always memorable and significant in ladies' life. Emotional reactions are different among cultures and countries. Menarche is very important for a girl due to physiologic, psychologic and cultural effect. Negative emotions can develop if the girl hasn't got the true knowledge. The aim of this study is to determine the emotional reactions and traditional application of Turkish adolescents. A conversation form is used. The form included; age, education level, menarche age, level of knowledge about menarche, emotional reaction about menarche, tradional application with regard to menarche. A descriptive research was performed. Data was collected between 1 March-31 August 2011. The sample consisted of 1465 adolescent from seven differ region of Turkey. The mean age of the sample was $20.26 \pm 2.34$ and $84.6 \%$ of them were university students. Mean menarche age was $13.28 \pm 1.25$ (min:10, max:19). Most sense emotional status at menarche were; $35.2 \%$ "I was affaid", $35.8 \%$ "I was surprised", 10.1\% "I'm glad", 6.8\% "I was blush", 4.5\% "I was sorrow". It is of great importance to give adequate information to girls concerning menarche.
\end{abstract}

Keywords: Menearche, Adolescent, Emotional Reactions

\section{Türk Adolesanlarda Menarş ve İlk Duygusal Tepkiler}

\begin{abstract}
Özet
Menarş bir kadının yaşamında her zaman hatırlanan önemli bir fizyolojik olaydır. Mentrüel kanama ve menarşa bakış açısı; bireysel, toplumsal ve kültürel farklılıklar gösterebilir. Bazı toplumlarda gizlenmesi gereken ve utanılan bir hastalık/rahatsızlık durumu olarak algılanırken bazı toplumlarda büyümenin işareti olan bir mucizedir. Bu çalışmanın amacı Türk adolesan kızlarda menarşa yönelik ilk duygusal tepkileri ve geleneksel uygulamaları tanımlamaktır. Tanımlayıcı bir çalışmadır. Verilerin toplanmasında yapılandırılmış görüşme formu kullanılmıştır. $\mathrm{Bu}$ form; yaş, eğitim düzeyi, menarş yaşı, menarşa yönelik bilgi, ilk duygusal tepki ve geleneksel uygulamaları içermektedir. Veriler 1 Mart -31 Ağustos 2011 tarihleri arasında toplanmıştır. 1465 adolesan ile görüşülmüştür. Katılımcıların yaş ortalaması 20.26 olup \%84.6'sı üniversite öğrencisidir. Menarş yaş ortalaması 13.28 bulunmuştur. Menarşa yönelik yaşanan ilk tepkiler \%35.2 "korktum”, \%35.8 “sürpriz oldu”, \%10.1 “sevindim”, \%6.8 "utandım” ve \%4.5 "üzüldüm” olarak belirtilmiştir. Menarş ile ilgili olarak genç kızlara yeterli bilgi verilmesi önemlidir.
\end{abstract}

Anahtar Kelimeler: Menarş, Adolesan, Duygusal Tepkiler 


\section{Introduction}

Menstruation is defined as throwing the endometrium layer out periodically. Menarche is the first menstruation bleeding starting with the hormonal changes (Deurgate et al., 2004). Even though the menarche age is related with genetic, socio-economic status, nutrition, and geographic regions, the avarage menarche age was found 11.67-13.59 at international studies (Tang et al., 2003, Saka and Neyzi, 2005, Yeung et al., 2005, Deo and Ghattargi, 2005).

Menarche is a psyhological event which is always recalled by the woman. Menstrual bleeding and perception of menarche might show individual, social and cultural differences. It is a magical sign of growing up for some societies whereas it is perceived as a disgraceful illness and needs to be kept as secret. Similarly, while some societies celebrate menarche, for others it is even forbidden to talk about it (Ince, 2001, Turan and Ceylan, 2007).

Fear, sorrow, embrassment, feelings herself dirty, and such negative feelings are stated as the first responses to menarche at many national and international studies (Tang et al., 2003, Demirel and Terzioglu, 2003, Uskul, 2004, Jorm et al., 2004, Tortumluoglu et al., 2004, Yeung et al., 2005, Deo and Ghattargi, 2005, Turan and Ceylan, 2007, Chang et al., 2010, Ozdemir et al., 2011, Mcmahan et al., 2011).

Menstruation is one of the crucial periods of being a woman. The women meets physical, emotional and behavioral changes in more than half of their lives (Turan and Ceylan, 2004). An adolesecent's knowledge of menarche, source of that knowledge, problems she meets, responses to those problems and ways she uses to overcome those problems might provide data about menstrualpremenstrual problems she will come across throughout her life (Tasc1, 2006).

How healthy women have the society, healthier generations will come up. Menarche is an important process for the women with its pysologic, physologic and cultural effects. Not having any knowledge or having negative knowledge of beliefs may cause negative emotions through her whole life. As health professionals, midwives and nurses; we should take women's responses, behaviors and cultural environment for menarche and menstrual bleeding into consideration.

The number of studies on Menarche of Turkish Adolescences are fairly limited hence; this study is planned in order to provide and gather data fort he Literature about knowledge , emotions, and traditional applications for the 12-25 year old Turkish adolesecences.

\section{Methods}

This is a descriptive study and the required data were obtained between the dates of March 1st and August 31st, 2011. Researche universe consists that female student stayed dormitories at Istanbul. The sample consist of 1465 female student living in Istanbul as a student and accepting paricipate in the study as well.

A Questionarre which was prepaired by the researchers, used for gathering the required data. Age, menarche age, place of the first menarche, feelings at the moment of the first menarche, emotional responses to the first menarche, sources of information, the person with whom the first experince was shared were all quesitoned by items of the quesitionarre form. The form was filled by the students of Marmara University, Health Sciences Faculty, Midwifery Department by interviewing with the female adolesences staying in student dormitories in Istanbul. Participants were given information about the research and their contents were obtained.

As for the calculation of the recommended sample's size; the number of female student that state Credit and Dormitories Agency in Istanbul at 2011 (N=9522) (www.kyk.gov.tr). It was found out as 
370 person with $95 \%$ reliability and $5 \%$ tolerance. Istanbul is a cosmopolitan city, this is facilitate acces to adolescent from different regions. 1700 participants took place in the research and some of the items were removed due to the lack of required data. For the 1465 cases, the answers were categorized and the frequency distribution were made. The frame between the very first responses to menarche and information retrieval status was used and the direction of the relationship was determined through chi square and pearson correlation analysis.

\section{Findings}

In the study the avarage age was found out as $20.27 \pm 2.3$ (min:18, max:25) and the avarage menarche age as $13.28 \pm 1.25$ (min:10, max:19). $84.6 \% \quad(n=1238)$ of the adolescences participating in the study were univeristy student, $15.4 \%$ of them $(\mathrm{n}=227)$ had master student. $95.6 \%(\mathrm{n}=1400)$ of the adolescences stated that they remember where they experienced the first menarche and $67.9 \%(n=995)$ of them stated that they experinced the first menarche in their own houses and $13.9 \%(n=204)$ of them at school. Regions where participant's grow; 24.8\% $(\mathrm{n}=363)$ Marmara region, $7.4 \%(\mathrm{n}=108)$ Aegean region, 22.9\% $(n=336)$ the Black Sea region, 12.6\% $(n=185)$ Mediterranean region, $12.8 \%(n=187)$ Central Anatolia Region, 10.4\% $(n=153)$ Eastern Anatolia region, 9.1\% $(n=132)$ Southeast Anatolia region.

When the participants were asked what they felt at the moment of the first menarche; $35.2 \%(\mathrm{n}=$ $516)$ of them replied as "fear", $35.8 \%(\mathrm{n}=525)$ as "astonishment", $10.1 \%(\mathrm{n}=148)$ as "rejoice", $6.8 \%$ $(\mathrm{n}=100)$ as "disgrace" and $4.5 \%(\mathrm{n}=66)$ as "sorrow".

First emotional responses were compared with menarche age and information retrieval status in the study and a strong relation between menarche age and feelings of "fear" and "rejoice" in addition; a strong relation between information retrieval status and the feelings of "fear", "astonishment", "rejoice" were found out.

Table 1. Distribution of First Behavioral Responses to Menarche

\begin{tabular}{|l|l|l|}
\hline First Behavioral Responses & Frequency & Percent \\
\hline Told my mother & 742 & 50,6 \\
\hline Did nothing, accept it as normal and bought pad & 225 & 15.4 \\
\hline Told my sister & 107 & 7,3 \\
\hline Cried & 103 & 7,0 \\
\hline Hided it and went to bed immediately & 72 & 4,9 \\
\hline Confused, worried, fainted & 46 & 3,1 \\
\hline Told my friend & 38 & 2,6 \\
\hline Told my relatives (aunt,grandma..etc) & 29 & 2,0 \\
\hline Don't remember & 103 & 7,0 \\
\hline Total & 1465 & 100,0 \\
\hline
\end{tabular}

When it was asked what they did as soon as they experienced menarche; $50.6 \%(\mathrm{n}=742)$ of them replied as "told my mother" $14.5 \%(\mathrm{n}=212)$ as "bought a hygenic pad", $7 \%(\mathrm{n}=103)$ of them as "cried", 7\% (n=103) of them as "don't remember" (Table 1) 
Table 2. The Distrubition of the People With Whom The First Menarche Experince Was Shared.

\begin{tabular}{|l|l|l|}
\hline & Frequency & Percent \\
\hline Mother & 1036 & 70,7 \\
\hline Friend & 158 & 10,8 \\
\hline Sister (elder/younger) & 152 & 10,4 \\
\hline Relative (aunt,cousin..) & 59 & 4,0 \\
\hline Noone & 23 & 1,6 \\
\hline Teacher & 21 & 1,4 \\
\hline Father & 7 &, 5 \\
\hline Don't remember & 9 &, 6 \\
\hline Total & 1465 & 100,0 \\
\hline
\end{tabular}

The person, with whom the first menarche experience was shared, was stated by the adolescences as: $70.7 \%(n=1036)$ mother, $10.8 \%(n=158)$ friend, $10.4 \%(n=152)$ sister and $1.6 \%(n=23)$ no-one (Table 2).

Table 3. The Primary Source of Information for Menarche

\begin{tabular}{|l|l|l|}
\hline & Frequency & \multicolumn{1}{c|}{ Percent } \\
\hline Mother & 803 & 54,8 \\
\hline Friends & 244 & 16,7 \\
\hline Teacher & 125 & 8,5 \\
\hline Health professionals & 142 & 9,7 \\
\hline Sister-cousin-aunt-books & 151 & 10,3 \\
\hline Total & 1465 & 100,0 \\
\hline
\end{tabular}

$87.8 \%(\mathrm{n}=1286)$ of the adolescences replied as "yes" when they were asked whether they had sufficient information before experiencing menarch. As for the primary source of information on menarche they stated: $54.8 \%(\mathrm{n}=803)$ mother, friend $16.7 \%(\mathrm{n}=244)$, teacher $8.5 \%(\mathrm{n}=125)$ and health professionals $9.7 \%(n=142)$. The rate of using hygenic pad was found $87.7 \%$ in the study (Table 3 ).

\section{Discussion}

Menearche age is related with many variables such as socio-cultural status, geographical region etc... the avarage menarche age was found 11.67-13.59 at international studies (Tang et al., 2003, Saka and Neyzi, 2005, Yeung et al., 2005, Deo and Ghattargi, 2005). In studies, early menarche age have been associated with negative conditions childhood sexual abuse, anxiety, depression and suicidal tendency (Boynton et al., 2013, Deng et al., 2012, Natsuaki et al., 2011 ). Late menarche age have been associated with physical abuse (Boynton et al., 2013). The study in which we examined the menarche stories of Turkish adolescents, avarage menarche was found 13.28 \pm 1.25 . Avarage menarche age was found $13.3 \pm 1.3$ by Tekgul et al. (2005), in their studies with 121.499 participants and it is similar to our study's results.

Feelings and attitudes about menarche that is the sign of transition to adolescence include sociocultural differences (Chrisler and Zittel, 1998, Uskul 2004, Lee, 2008, Chang et al., 2010). First emotional responses to menarche are; fear $35.2 \%$, astonishment $35.8 \%$, embrassment $6.8 \%$, sorrow $4.5 \%$, and rejoice $10.1 \%$ in our study. Fear, sorrow, embrassment, feelings herself dirty, and such negative feelings are stated as the first responses to menarche at many national and international 
studies (Tang et al., 2003, Demirel and Terzioglu, 2003, Uskul, 2004, Jorm et al., 2004, Tortumluoglu et al., 2004, Yeung et al., 2005, Deo and Ghattargi, 2005, Turan and Ceylan, 2007, Chang et al., 2010, Ozdemir et al., 2011, Mcmahan et al., 2011).

In the study, moreover, a strong relation was determined between the feelings of fear, astonishment, rejoice and menarche age and information retrieval status (Tang et al., 2003, Jorm et al., 2004, Yeung et al., 2005, Chang et al., 2010). That emphasises the importance getting the girls ready beforehand.

Among the first behavioral responses to menarche are in our study; telling it someone (mothersister-friend) $62.5 \%$, buying pads $15.4 \%$, hiding and crying $11.9 \%$ (Table 1). Uskul (2004), after he made focus group interwievs with 53 women and from 34 different countries, expressed that cultural and religious beliefs to which women are exposed, highly effects the very first reactions to menarche. Family has a regulatory role in that process and individual differences are so effective for those reactions.

Yeung et al. (2005) analyzed the emotional expectations of the girls before menarche in China and they emphasised that the girls had mostly negative feelings like embrassment and the only positive feeling was to accept the situation as normal. Also, from western studies he examined, he points out that menarche was perceived as a physical illness and set an obstacle for social life and activities. As a result of focus group interwievs made in Kenya with 48 primary school student and 9 teachers, young girls mostly express their feelings about menstruation as "disgrace", "fear" and "confusion". The reason why they feel "disgrace" is the concern of being noticed by other people (Mcmahan et al., 2011). Chang et al. (2010) in his systematic review puts forth that menarche has a major effect on women's lives and also girls experience pyhsologic, physological, and socio-cultural changes. Furthermore; he emphasises the importance of being to menarche and the importance of school nurses as well.

In our study, when it was asked with whom they shared the first menarche experinces, $70.7 \%$ of the participants replied as "mother", $10.8 \%$ of them as "friend" and $10.4 \%$ of them as "sister" (Table 2). In many studies it seems that mother is the first person $(44.5 \%-78.5 \%)$ with whom the menarche experience is shared; friends and sisters are the second and third people respectively (Tang et al., 2003, Demirel and Terzioglu, 2003, Tortumluoglu et al., 2004, Yeung et al., 2005, Turan and Ceylan 2007, Ozdemir et al., 2011). Tortumoğlu et al. (2004) expressed that $44.5 \%$ of the girls share the first menarche experience with their mothers however; those who dont share it with anyone have the feelings of fear $(34.3 \%)$ and disgrace $(65.7 \%)$. In recent years reported that negative attitude about menarche decriced in new generation adolescent. Adolescents are taking knowledge and support about menarche fron internet and social networks (Liu et al., 2012).

Özdemir et al. (2011) found out in his study which he made in Eastern Anatolia that $64.9 \%$ of the girls share the experince with their mothers but so few mother feel happy for that experience of their girls. The rate of mothers kissing their girls $18 \%$ and congragulating their girls $11.3 \%$. Lee (2008) examined the menarche experiences of 155 girls and their mothers stated that positive menarche experience has no guarantee in spite of the support from their mothers. Nonetheless; mothers' care reduces the negative feelings such as "disgrace" and "humiliation".

In this study the rate of "getting sufficient information about menarche beforehand" was found $87.8 \%$ and it was stated that source of the information varies in different rates: mother $54.8 \%$, friend $16.7 \%$, health professionals $9.7 \%$, and teacher $8.5 \%$. As for "getting information beforehand" the rates of other studies are: Demirel and Terzioglu (2003) 42.5\%, Tortumoğlu et al. (2004) $14.6 \%$, Turan-Ceylan (2007) 90.0\%, and Özdemir et al. (2011) 52.6\%. Such different results might be related with the place of the research and the age group of the participants as well. Yeung et al. (2005) in their study made in China, stated the rate of getting adequate information as $51.6 \%$. In the study it was 
emhasized that negative effects of menarche were related with insufficient preparation. Especially, important that emotional aspects should discussions for preparation before the menarche (Marvan et al., 2012).

Demirel and Terzioglu (2003) states in his study which he did in Gaziantep, that $80.9 \%$ of the girls want to get the primary information from their mothers. So that; designing education programmes for parents is highly important. Deo and Ghattargi (2005) observed the differences of experiencing menarche in rural and urban areas in his study. He concluded that in rural areas the primary source of information was mothers (27.5\%) and it was teachers in urban areas (27.1\%). Özdemir et al. (2011) stated in his study he did in Eastern Anatolia, that the primary source of information was mothers but mothers inform their girls mostly on body hygiene $72 \%$, and genital hygiene $59.3 \%$. That is; the emotional support is so limited.

Chang et al. (2010) emphasises the importance of school nurses and adds that the school nurses should have required information on sexual health so that they are able to provide necessary information to the students. Chrisler and Zittel (1998) in his research he did in 4 different countries with univeristy students as paticipants, puts forth that women learn to hide menstruation symptoms so that, there isn't enough information about the first menarche experience. He also recommends that there should be more study on that issue.

In our study, the rate of using hygienic pads was determined as $87.7 \%$ and it was $96.7 \%$ in TuranCeylan's (2007) study. Tortumoğlu (2004) expressed in his study held in rural area that $55.5 \%$ of the girls use cloth and $44.5 \%$ of them use cotton-pads. On the other hand; the study which was done in Kenya emphasises the necessity of organizing national education progammes on using hygienic pads and being ready for menarche (McMahan et al., 2011). In our study; having a high rate of using hygienic pads is rejoicing and it might be related with increasing attainability of hygienic pads within last 15 years.

\section{Conclusion and Recommendations}

Getting insufficient or wrong information effects the women throughout the generations. Hence; it is highly important to design education programmes in pre-menarche period. We might propose that training program about menarche sould contain knowledge and emotional support.

Relevance to clinical practice: nurses and midwives, having the main role in child's and families' health, should develop their roles as trainers and counselors.

Contributions: This study submitted oral presentation on 1st. PNAe Congress on Pediatric Nursing. Promoting Excellence in Pediatric Nursing Care. 1-2 December 2011, Istanbul, Turkey. 


\section{References}

Boynton, R. J., Wright R. J., Putnam F. W., Hibert, E. L., Michels K. B., Forman M. R., Edwards J.R. 2013. Childhood Abuse and Age at Menarche. Journal of Adolescent Health 52, 241-247.

Chang, Y. T., Hayter, M., Wu, S. C. 2010. A sistematic review and meta-ethnograpy of qualitative literatüre, experiences of menarche. Journal of Clinical Nursing, 19, 447-460.

Chrisler, J. C., Zittel, C. B. 1998. Menarche stories:reminscences of college students from Lithuania, Malaysia, Sudan and United States. Health care for Women International, 19(4), 303-312.

Demirel, S., Terzioğlu, F. 2003. Assesment of level of knowledge on menstruation physiology

of $5^{\text {th }}$ and $6^{\text {th }}$ grade girls enrolled at primary school in Sahinbey Distric Gaziantep Province. Journal of Research and Development in Nursing, 5(2), 47-60.

Deng, F., Tao, F.B., Wan, Y., Hao, J., Su, P., Cao Y. 2011. Early Menarche and Psychopathological Symptoms in Young Chinese Women. Journal Of Women's Health, 20, 207-214.

Deo, D. S., Ghattargi, C. H. 2005. Perception and practice regarding menstruation. A

compherensive study in urban and rural adolescent girls. Indian Jornal of Community Medicine, $30,1$.

Deurgate, C. M., Buyalos, R. P., Laufer, L. R. 2004. Adolescents and developmental disorders of adolescent. In: Hacker, N. F., Moore, J. G., Gambone, J. G., eds. Essentials of Obstetrics and Gynecology: Elsevier Saunders, 387-397.

Ince, N. 2001. Premenstrüel syndrome in adolescence. T. Clin J. Med. Sci, 21, 369-373.

Jorm, A. F., Christensen, H., Rodger, B., Jacomb, P. A., Easteal, S. 2004. Association of adverse childhood experiences, age of menarche and adult reproductive behavior;does the androgen reseptör gene play a role?. American Journal of Medical Part B, 125B, 105-111.

Lee, J. 2008. A kotex and simile, mothers and daughters at menarche. Journal of Family Issues, 29(10), 13251347.

Liu, H. L., Chen K. H., Peng N. H. 2012. Cultural Practices Relating to Menarche and Menstruation among Adolescent Girls in Taiwand Qualitative Investigation. Pediatr Adolesc Gynecol, 25, 43-47.

Marvan, M. L., Abolnik M. M. 2012. Mexican Adolescents' Experience of Menarche and Attitudes Toward Menstruation: Role of Communication Between Mothers and Daughters. J Pediatr Adolesc Gynecol, 25, 358-363.

Mcmahan, S. A. Et. Al. 2011. The girl with her period is the one to hang her head' Reflectations on menstural menagement among schoolgirls in rural Kenya. BMC International Health \& Human Rights, 11, 7.

Natsuaki M. N., Leve, L. D., Mendle, J. 2011. Going Through the Rites of Passage: Timing and Transition of Menarche, Childhood Sexual Abuse, and Anxiety Symptoms in Girls. Journal of Youth Adolescence, 40, 1357-1370.

Ozdemir, F., Nazik, E., Pasinlioğlu, T. 2011. Determination of the motherly reaction to adolescent's experiences of menarche. II. North American Society and Adolescent Gynecology, 24, 21-24.

Saka, H. N., Neyzi, O. 2005. Onset of puberty is it shifting to youngers ages?. Turkish Archives of Pediatrics, 40, 7-14.

Tang, C. S., Yeung, D. Y., Lee, A.M. 2003. Psyhosocial corralates of emotional responses to menarche among Chinese adolescent girls. Journal of Adolescent Health, 33(3),193-201. 
Tasci, K. D. 2006. Evaluation of nursing students' premenstuel symtoms. TAF Preventetive Medicine Bulletin, $5(6), 434-443$.

Tekgul, N., Saltik, D., Sen, Y., Kurt S. 2005.The menearche age in women of 15-49 ages.

STED, 14(4), 76-79.

Tortumluoglu, G., Özyazicioğlu, N., Tüfekçi, F., Sezgin, S. 2004.The description of emational reaction anda ge at menarche in a rural areas. Ataturk University Journal of Nursing School, 7(2), 7688.

Turan, T., Ceylan, S. S. 2007. Determination of 11-14 year old primary student's practices and knowledge about menstruation. FSHD-Journal of Firat Health Services, 2(6), 41-54.

Uskul, A. K. 2004. Women's menarche stories from a multicultural sample. Social Science\&Medicine, 59, 667679.

Yeung, D. Y. L., Tang, C. S., Lee, A. 2005. Psychosocial and culturel faktors influencing expectation of menarche. A study on Chinese premenarcheal teeneage girls. Journal of Adolescent Research, 20(1), 118135. 